\title{
THE MEANING AND RANGE OF THE PRINCIPLE OF SELF-DETERMINATION
}

\author{
M. K. NAWAZ*
}

GEVERAL questions have been raised in connection with the prin-

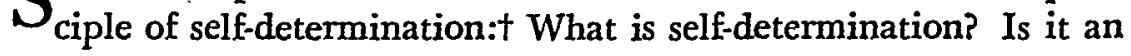
individual right or that of a people? What are the circumstances and conditions under which self-determination can be applied? Are there any limitations governing the principle of self-determination? Answers to these questions have varied considerably, some of them going to the extent of denying that self-determination belongs in the province of law at all. ${ }^{1}$ Such a view cannot remain unchallenged in a legal inquiry. It is incorrect inasmuch as it assumes that there is a dichotomy operating at the conceptual level. Self-determination, like other United Nations Charter concepts such as domestic jurisdiction and aggression, belongs as much to the province of law as of politics, and no useful purpose will be served by setting "law up against politics, or politics against law . . . better by far 'to find

- A.B. 1947, Andhra University; LL.B. 1951, LL.M. 1953, Madras University. Research Associate, Duke University Rule of Law Research Center. The author gratefully acknowledges the assistance of Mr. Robert Scott of the Duke University School of Law in the collection of historical material used in the preparation of this article.

$f$ Concerning a bibliography on self-determination, it may be said in general that treatises on international law contain little, if any, information. Oppenheim and Brierly, two of the leading British authorities, make no mention of self-determination. See Brierly, The Law of Nations (5th ed. 1955); Oppenheim, International Law (8th ed. 1955). As to American writers, Briggs and Bishop refer to self-determination in their case books, but do not deal with the subject adequately. See BusHop, INTERnational LAW 274 (2d ed. 1962); BRigcs, The Law of Nations 65 (1952). Continental writers have devoted more attention to self-determination. See, e.g., DE Vissciler, TheORY and Reality in Public International Law 54-80, $128-29$ (1957); Verdross, VöLKRRRECHT 41, 226, 428 (1959). Levin has recently analyzed the Soviet doctrine of self-determination. Levin, The Principle of Self-Determination of Nations in International Law, Sovitr YB. INT'L LAw' 45 (1964).

The most important source of information concerning self-determination is, of course, the documents of the League of Nations and the United Nations. Higgins hás recently analyzed United Nations practice. Hicgins, THE Development of INTERnational Law Through the Polmtical Organs of the Unimed Nations 90.106 (1963).

1 "The right of self-determination has as yet found no stable place in the international legal structure nor has it been accepted by states as a policy to be applied consistently and across the board. Indeed, $I$ would suggest that it is essentially miscast in the role of a legal right which can be made an operative part of either domestic or international systems." EMERson, From EMPIRE to NATION 307 (1960). 
within the limits of power the elements of common interest on the basis of which joint action and agreed standards [can] . . . be established." "2 The argument also gives inadequate regard to the developments that have been taking place in the field of self-determination in the United Nations. Although this is not to imply that the scope of the principle of self-determination can be defined once and for all, nor that its future course can be predicted with mathematical precision, the context in which it operates can be set forth and the juridical aspects of the doctrine of self-determination can be outlined.

\section{Self-Determination in Historical Perspective}

Historically speaking, certain aspects of the principle of selfdetermination are as old as the nation state. ${ }^{3}$ The best known historical instances of self-determination are probably the American and French Revolution. Nevertheless, international legal doctrine was slow to recognize the juridical significance of self-determination, notwithstanding the writings of several early French jurists. ${ }^{4}$ Woodrow Wilson, however, effected profound changes in regard to self-determination. It was probably Wilson, more than any other person, who first contributed to a theory of self-determination. ${ }^{5}$ Wilson never precisely defined the principle of self-determination, but his predilections were manifested in his statement to the effect that "national aspirations must be respected; peoples may now be dominated and governed only by their own consent. 'Self-determination' is not a mere phrase it is an imperative principle of action . . . ."8 Also relevant in this connection is the fifth of Wilson's Fourteen Points:

A free, open-minded, and absolutely impartial adjustment of all colonial claims, based upon a strict observance of the principle that in determining all such questions of sovereignty the interests

\footnotetext{
2 Higgins, The Development of International Law Through the Political Organs of the United Nations 9 (1963).

${ }^{3}$ See generally Cobban, Nattonal Self-Detremination (1944).

- An excellent summary of the views of several French writers, including Holtzendorff, Bluntschli, Bonfils, Despagnet, Hall and Phillimore, will be found in WAMBAugh, A Monograph on Plebiscites 22-26 (1920).

5 "Nearly forty years ago a Professor of Political Science who was also President of the United States, President Wilson, enunciated a doctrine which was . . . widely accepted as a sensible proposition, the doctrine of self-determination." JENNINGs, The APPROACH TO SELF-GOVERNMENT 55-56 (1956).

- 1 The Public Papers of Woodrow Wilson, War and Peace 180 (Baker \& Dodd eds. 1927).
} 
of the populations concerned must have equal weight with the equitable claims of the government whose title is to be determined. 7

The essence of the Wilsonian concept of self-determination consisted of the notion of self-government of peoples. Similar views have been expressed by other commentators. "The doctrine of national self-determination," says Sarah Wambaugh, "is based on and inseparable from that of popular sovereignty."8 More recently, Kurt Rabl has said that

viewed in historical perspective, the doctrine of the 'right of selfdetermination' has evolved to mean that no people must be forced to live under foreign domination or under a constitutional system which it does not agree to. Every people has the right to live within its own territory in external freedom and internal liberty. ${ }^{\circ}$

There is also considerable theorizing among the Communists on the subject of self-determination. Here, of course, a doctrine of self-determination ${ }^{10}$ has developed which varies considerably from the Wilsonian concept. Stalin, who is reported to have written extensively on the subject, once argned that "the right to self-determination cannot and must not serve as an obstacle to the exercise by the working class of its right to dictatorship. The former must give way to the latter."11 Since the Soviet doctrine operates within the over-all framework of Marxist political thought, it is necessarily a limited one.12

\section{Self-Determination and the League of Nations}

As noted above, the principle of self-determination occupied an almost pivotal position in the political philosophy of Woodrow Wilson. ${ }^{13}$ Wilson's contribution, however, consists not merely in his having recognized the importance of the doctrine but also in his

\footnotetext{
3 Williams, Some Aspects of the Covenant of the League of Nations 243 (1934).

- Wambaugh, op. cit. supra note 4, at 2.

- Rabl, Das Selbstbestmmaungsrecht der Volker 272 (1963).

${ }^{10}$ For an excellent account of the Bolshevik doctrine of self-determination see 1 GARR, THE Bolshevik ReVolution, 1917-1923, at 410-28 (1950). For a more recent Soviet interpretation of self-determination, see Levin, The Principle of Self-Determination of Nations in International Law, Soviet YB. INT'L LAW 45 (1963).

11 Stalin, Marxism and the National and Colonial Question 168 (2d ed. 1936), quoted in COBBAN, op. cit. supra note 3, at 107. See also I CARR, op. cit. supra note 10 , at 426.

12 For a survey of Soviet attitudes, see Goodman, The Cry of National Liberation: Recent Soviet Attitudes Towards National Self-Determination, 14 INT'L ORGANIzATION 92-106 (1960).

${ }^{18}$ Cobban, op. cit. supra note 3 , at 13.
} 
having taken measures to institutionalize it. Wilson once stated that "if the desire for self-determination of any people in the world is likely to affect the peace of the world or the good understanding between nations, it becomes the business of the League. . . ."14 Jessup has pointed out that "Wilson believed an international organization was needed to transform the doctrine of self-determination into political reality."15 For Wilson, the implementation of self-determination was to become one of the essential functions of the League of Nations; self-determination was to constitute an integral part of the League. ${ }^{16}$ Yet the Covenant of the League of Nations did not contain any explicit reference to self-determination. Article 3 of the original draft of the Covenant proposed by Wilson explicitly mentioned the principle of self-determination:

The Contracting Powers unite in guaranteeing to each other political independence and territorial integrity; but it is understood between them that such territorial readjustments, if any, as may in the future become necessary by reason of changes in present racial conditions and aspirations or present social and political relationships, pursuant to the principle of self-determination, and also such territorial readjustments as may in the judgment of three fourths of the Delegates be demanded by the welfare and manifest interest of the peoples concerned, may be effected if agreeable to those peoples....17

The draft article underwent several changes at the Paris Peace Conference, however, and "due to the opposition of the statesmen who represented the British Empire," the reference to self-determination was eliminated. ${ }^{18}$ This is not to say, however, that there was no reflection of the principle of self-determination in the Covenant. Article 22 relating to mandates was a partial recognition of the principle of self-determination. ${ }^{19}$ The significance of article 22 was the fact that it attacked the doctrine of sovereignty. The theory that the State had to render an account to an international organi-

24 2 The Public Papers of Woodrow Wilson, War and Peace 244 (Baker \& Dodd eds. 1927), quoted in CoBban, op. cit. supra note 3, at 27.

${ }^{16}$ Jessup, Self-Determination Today in Principle and in Practice, 33 VIRGINIA QUARTERLY 174, 177 (1957).

${ }^{10}$ CobBan, op. cit. supra note 3 , at 44 .

${ }^{17}$ Lansing, The Peace Negotiations-A Personal. Narrative 93 (1921).

${ }^{28} I d$. at $94-95$.

10 "Indeed, Point 5 of the Fourteen Points, when it emphasizes the principle of safeguarding 'the interests of the populations concerned' in the adjustment of all colonial claims, may be taken as opening the door to something in the nature of the Mandatory scheme." WrLIaMs, op. cit. supra note 7, at 201. 
zation, which was the quintessence of the mandate system, was certainly new to international law. Williams has said that "this is a clear and incontrovertible assertion of the existence of something superior to the State in human affairs."20

Several questions arose concerning the relations between sovereignty and the mandate system, the most intricate of which was who was sovereign in a mandated territory. Numerous answers have been given to this question which once plagued international lawyers. ${ }^{21}$ While it may not be easy to say which of these answers is correct, it can be said that the view that the mandatory should be regarded as the sovereign of the territory is open to serious doubt.22 Such a thesis would rob the mandate system of its meaning and usefulness. Also of some significance here is the question of who is entitled to change the status of a mandated territory. It is submitted that if a mandatory is not the sovereign of a mandate, a fortiori it cannot change the status of the mandated territory. "[T] Nations," says Quincy Wright, "seems competent and alone competent to change the status of territory now under article 22."20 Furthermore, it should be noted that the disappearance of the League of Nations in no way enlarges the powers or authority of the mandatory, nor does it remove the mandatory from the category of mandatories.

\section{The Case of the Aaland Islands}

During the League period several problems connected with, or bearing upon, the principle of self-determination arose, and the League of Nations had to grapple with them, notwithstanding the fact that the Covenant contained no reference to self-determination. For example, in the controversy between Finland and Sweden in 1920 concerning the Aaland Islands, the International Committee of Jurists, appointed by the Council of the League, considered the bearing of self-determination on the relative merits of the parties. ${ }^{24}$

\footnotetext{
${ }^{20} \mathrm{Id}$. at 206.

21 See 1 OpPeNHEIM, InTERNATIONAI LAw 222 n.5 (8th ed. 1955).

${ }^{28}$ But see Rex v. Christian, [1924] So. Afr. L.R. App. Div. 101 (1923), where the appellate division of the Supreme Court of South Africa held that the mandatory, that is, the Union of South Africa, had sufficient internal majestas to support a conviction of one of the inhabitants of South-West Africa for high treason. This decision is sometimes invoked in support of the theory of sovereignty of the manda. tory in respect of the mandate.

${ }_{28}$ WRIGHT, MANDATES UNDER THE LEAGUE OF NATIONS 506 (1980).

s" For a statement of the Finnish and Swedish cases concerning the Aaland Islands,
} 
The Committee of Jurists, referring to self-determination, observed that:

Although the principle of self-determination of peoples plays an important part in modern political thought, especially since the Great War, it must be pointed out that there is no mention of it in the Covenant of the League of Nations. The recognition of this principle in a certain number of international treaties cannot be considered as sufficient to put it upon the same footing as a positive rule of the Law of Nations.

On the contrary, in the absence of express provisions in international treaties, the right of disposing of national territory is essentially an attribute of the sovereignty of every State. Positive International Law does not recognize the right of national groups, as such, to separate themselves from the State of which they form part by the simple expression of a wish, any more than it recognises the right of other States to claim such a separation. ${ }^{25}$

This statement of the Committee of Jurists has sometimes been invoked in support of the thesis that self-determination has no basis in international law. ${ }^{26}$ There are several objections to this view. First, this is not a complete statement of the Committee of Jurists' exposition on self-determination. The Committee of Jurists said in a later passage that:

Under such circumstances, [those arising in the context of revolutions and wars] the principle of self-determination of peoples may be called into play. New aspirations of certain sections of a nation, which are sometimes based on old traditions or on a common language and civilisation, may come to the surface and produce effects which must be taken into account in the interests of the internal and external peace of nations.

The principle recognising the rights of peoples to determine their political fate may be applied in various ways; the most important of these are, on the one hand the formation of an independent State, and on the other hand the right of choice between two existing States. ${ }^{27}$

see League of Nations Off. J., Special Supp. No. 1, Aug. 1920, pp. 3-24. In this case, while Sweden invoked the principle of self-determination, Finland denied its applicability. Sweden argued that: "There is no need to remind the Council that when peace was being concluded endeavours were made, in tracing the frontiers of the new States, to apply as far as possible the lofty principle of the right of selfdetermination of the peoples which the Peace Conference proclaimed. This principle is expressed with particular force in the reply of the Allied and Associated Governments to the German counter-proposals of 15th June, 1919." Id. at 22.

${ }^{25} I d$., Special Supp. No. 3, Oct. 1920, p. 5.

${ }^{20}$ EMERSON, op. cit. supra note 1, at 303 .

${ }^{97}$ Leacue of Nations Off. J., Special Supp. No. 3, Oct. 1920, p. 6. 
This part of the committee's exposition may not warrant the conclusion that self-determination is a principle of international law, but it certainly justifies the conclusion that the Committee of Jurists recognized the significance of the principle of self-determination in certain circumstances. Furthermore, insofar as the principle of selfdetermination represents a new development in international law, it is not fair to judge its validity on the basis of the traditional rules of international law which it seeks to modify. In any case, many changes have occurred in the field of international law in general and with regard to self-determination in particular since the exposition of the Committee of Jurists.

\section{Self-Determination and the United Nations}

It may be mentioned at the very outset that self-determination occupies a far more important position in the United Nations than it did in the League of Nations. The expression "self-determination" is explicitly mentioned in two articles of the Charter. Article I (2) specifies one of the purposes of the United Nations to be the development of "friendly relations among nations based on respect for the principle of equal rights and self-determination of peoples, and to take other appropriate measures to strengthen universal peace." Article 55, relating to international economic and social cooperation, states that the United Nations shall promote certain objectives "with a view to the creation of conditions of stability and well-being which are necessary for peaceful and friendly relations among nations based on respect for the principle of equal rights and self-determination of peoples ...."

The first question that naturally arises here is what is meant by the concept of "self-determination" in the above articles? Second, what is the practice of the United Nations on self-determination, and in what way does United Nations practice clarify the meaning and content of self-determination? Any attempt to answer these questions must begin with an inquiry into the intentions of the founding members of the United Nations.

\section{Travaux Preparatoires}

It is of some interest to note that the Dumbarton Oaks draft of articles $1(2)$ and 55 did not contain any reference to self-determination. The Dumbarton Oaks proposal corresponding to article l (2) 
was designed simply "to develop friendly relations among nations and to take other appropriate measures to strengthen international peace." The expression "based on respect for the principle of equal rights and self-determination of peoples" was added for the first time at the San Francisco Conference at the instance of the four sponsoring powers, China, the United Kingdom, the United States, and the Soviet Union. ${ }^{28}$ The sponsoring powers left no definitive record as to what they meant by self-determination or what its meaning should be in the context of articles 1 (2) and 55. However, the committee which discussed the concept of self-determination had this to say:

Concerning the principle of self-determination, it was strongly emphasized on the one side that this principle corresponded closely to the will and desires of peoples everywhere and should be clearly enunciated in the Chapter; on the other side, it was stated that the principle conformed to the purposes of the Charter only insofar as it implied the right of self-government of peoples and not the right of secession. ${ }^{29}$

One may be tempted to say that this statement is not very helpful in determining the meaning of self-determination of peoples in article 1 (2). It may also be said, as, indeed, Henri Rolin of the Belgian delegation pointed out at the San Francisco Conference, that the usage of the terms "peoples" and "nations" in article $1(2)$ is confusing. ${ }^{30}$ In order to remove any possible doubts concerning the scope of self-determination in the proposed amendment, Rolin suggested the following text: "To strengthen international order on the basis of respect for the essential rights and equality of the states, and of the peoples' right of self-determination." 31 However, the Belgian proposal was rejected inter alia for the following reasons:

$[\mathrm{P}]$ aragraph 2 has for a purpose to strengthen universal peace and friendly relations on the basis of equality or right as stated. The equality of states was dealt with and accepted under Chap-

${ }^{2 B}$ It is said that the Soviet Union initiated the move for the addition of what subsequently became article $I(2)$ containing reference to "self-determination of peoples." In explaining the scope of this concept, Mr. Molotov is reported to have said at a press conference that the Soviet Union "attached first-rate importance" to the newly added principles of "equality and the self-determination of nations." These goals, it was alleged, would "draw [the] particular attention of the population of colonies and mandated territories," which would help to realize them sooner. Russell \& Muther, A History of the United Nations Charter 810-11 (1958). See also Levin, supra note 10.

${ }^{20}$ Doc. No. 343, I/1/16, 6 U.N. Conf. INT'L OrG. Docs. 296 (1945)

${ }^{80}$ Doc. No. 374, I/I/17, 6 U.N. CONF. INT'L ORG. Docs. 300 (1945).

21 Ibid. 
ter II, Principles, so it was irrelevant here to the point at issue.

[W] hat is intended by paragraph 2 is to proclaim the equal rights of peoples as such, consequently their right to self-determination. Equality "of rights, therefore, extends in the Charter to states, nations, and peoples. ${ }^{32}$

The full committee commented upon article 1 (2) as follows:

The Committee understands that the principle of equal rights of peoples and that of self-determination are two complementary points of one standard of conduct;

that the respect of that principle is a basis for the development of friendly relations and is one of the measures to strengthen universal peace;

that an essential element of the principle in question is a free and genuine expression of the will of the people ....83

A few comments may be germane here with regard to the drafting history of article 1 (2). First, the concept of self-determination embodied in article 1 (2) is distinct from the concept of equality of states mentioned in article 2(1). Second, the Charter concept of self-determination is closely connected with, and bears upon, the notion of the genuine will of the people in a given state. Beyond this, it is not clear, however, what the intentions of the founding members of the United Nations were with regard to self-determination in article 1 (2).

\section{Juristic Opinion}

It has been mentioned earlier that juristic opinion varies widely on the question of the nature of the principle of self-determination. To some writers, recognition of the principle of self-determination represents a new development in international law. ${ }^{34}$ To others it means nothing more than the declaration of an already existing rule of international law. ${ }^{35}$ Whatever the relative merits of these oppos-

\footnotetext{
${ }^{82}$ Doc. No. 723, I/1/A/19, 6 U.N. CoNF. INT'L ORG. Docs. 696, 704 (1945).

${ }^{33}$ Doc. No. 944, I/1/34 (1), 6 U.N. CONF. INT'L ORG. Docs. 445, 455 (1945).

" WRIGHT, INTERNATIONAL LAW AND the UNITED NATIONS 49 (1960). Levin says that the principle of self-determination, which expresses "the law consciousness of the masses," has become "a primary international legal principle." Levin, supra note 10, at 48 .

ss "The relevant provisions of the Charter were not creative of a new rule of law. All they did was to confirm and lay down in writing a principle which had long been growing and maturing in international society until it gained general recognition. By including and laying it down as one of the principles of the newly-born organization, the Charter gave expression to one of the elements of international law of the time." Lachs, The Law in and of the United Nations, 1 INDIAN J. INT'L. L. 429, 432 (1961).
} 
ing views, the fact remains that it is part of the United Nations Charter and has profound legal significance to contemporary world politics. On the question of the meaning and range of the principle, opinions among jurists also vary. According to Kelsen, "the formula of Article 1, paragraph 2, has the same meaning as the formula of Article 2, paragraph 1, in which the principles of sovereignty and equality are combined in a rather problematical way into one principle: that of "sovereign equality." "36 Kelsen arrives at this conclusion by interpreting the expression "self-determination of peoples" in article 1 (2) as sovereignty of the states. With all due respect. it is submitted that the conclusion and the reasoning leading thereto are open to doubt. They are inconsistent with the travaux preparatoires, ${ }^{37}$ and they cannot be supported by any known canon of treaty interpretation. It could scarcely be expected that the United $\mathrm{Na}$ tions Charter, a form of treaty, would mention one and the same concept in two articles. Consequently, the Kelsenian interpretation affords little assistance in construing article 1 (2). Ross, however, came very close to a correct interpretation when he wrote that selfdetermination means

a right for a people or a group (in a sociologico-ethnographical sense) to determine the national dependency of the territory inhabited. On the positive side this would mean a right to claim territorial changes in accordance with the wishes of the population; on the negative side it would mean that no territory could be ceded unless confirmed by a plebiscite. ${ }^{38}$

Ross' caveat, however, that it is 'quite impossible to define by any precise or rational criterion the group to which this right should belong. . . ."39 has marred the soundness of his interpretation, which, of course, is otherwise above reproach. This is neither to say that the principle of self-determination can be smoothly applied, nor that every demand for secession in the name of self-determination is to be considered rational. ${ }^{40}$ However, it is strongly urged that difficulties in the application of the principle of self-determination are by no means unique to that principle alone. What is

\footnotetext{
${ }^{80}$ Kel.sen, LAw of the UNited Nations 53 (1950).

${ }^{37}$ See text accompanying notes 28.33 supra.

${ }^{38}$ Ross, Constitution OF THE UNITED Nations 135 (1950).

so Ibid.

"We have no reason to disagree with the conclusion of DeVisscher that "applied without discernment, self-determination would lead to anarchy." DEVISSCHER, THEORY and Reality in Public International Law 128 (1957).
} 
required is the devising of useful criteria for determining the rationality of a demand for self-determination. Herein, as Eagleton has pointed out, lies "a new field of international law . . . being opened up; it deserves the most serious study . . ." W1 Within the United Nations it should become feasible to devise useful criteria and methods for ascertaining who the "peoples" are that are entitled to selfdetermination. Consequently, the scepticism raised in some quarters $^{42}$ as to the implementation of the principle of self-determination makes little sense. One may agree or disagree with a particular determination of the United Nations, ${ }^{43}$ for opinions can vary in this matter as well as others. However, the fact remains that the United Nations operates as a kind of guide and monitor of the principle of self-determination. One must, therefore, look into various relevant decisions of United Nations organs in order to ascertain the scope of self-determination.

\section{United Nations Practice}

Perhaps it is hardly necessary to point out the value and significance of the resolutions of the organs of the United Nations in the development and crystallization of concepts contained in the United Nations Charter. ${ }^{44}$ This becomes evident from an examination of United Nations resolutions relating to the colonial question ${ }^{45}$ and the doctrine of self-determination.

The principle of self-determination has been discussed on several occasions in the plenary meetings of the General Assembly, as well as in the sessions of the Trusteeship and Non-Self-Governing Territories Committee of the General Assembly. ${ }^{46}$ But for the most part, (1953).

"I Eagleton, Self-Determination in the United Nations, 47 AM. J. INT'L L. 88, 93

42 "On the surface it [the principle of self-determination] seemed reasonable: let the people decide. It was in fact ridiculous because the people cannot decide until somebody decides who are the people." JENnincs, op. cit. supra note 5, at 56.

"s See generally Eagleton, Excesses of Self-determination, 31 ForE1GN AFr. 592 (1953).

"See generally Sloan, The Binding Force of a 'Recommendation' of the General Assembly of the United Nations, 25 BRIT. YB. INT'L L. 1 (1948); Schachter, LAw AND FLexibiLity, ANN. REv. U.N. AFF. 173-86 (1952). Schachter has more recently analyzed in detail the effect of resolutions of United Nations organs, dissenting from the view that such resolutions have no juridical significance. Schachter, Interpretation of the Charter in the Political Organs of the United Nations, in LAW, STATE, AND INTERNATIONAL LEGAL ORDER: ESSAYS IN HONOR OF HANS KELSEN 270 (Engel ed. 1964).

"S See generally Nawaz, Colonies, Self-Government, and the United Nations, 11 INDIAN YB. INT'L AFF. 3 (1962).

'See generally HrgorNs, op. cit. supra note 2, at 90-106; Eagleton, supra note 41; Lachs, supra note 35. 
the discussions and resolutions of the General Assembly have concerned what is generally known as "classical" colonialism in such cases as Cyprus, Algeria, Indonesia, Tunis and Morocco. Despite the United Nations' present preoccupation with "classical" colonialism, however, there are also other forms to be considered. These have come to the fore as a result of the adoption of the now famous resolution concerning the granting of independence to colonial territories and peoples. ${ }^{47}$ The resolution "solemnly proclaims the necessity of bringing to a speedy and unconditional end colonialism in all its forms and manifestations." The question that arises here is what forms of colonialism are envisioned by the resolution? Although it is difficult to answer this question decisively, it is submitted that the resolution condemns all forms of colonialism. ${ }^{48}$

Another important aspect of the resolution is that it does not restrict the principle of self-determination to peoples living in colonies, but extends the principle to all peoples. Both the preamble and the operative part of the resolution in effect refer to selfdetermination as a principle of universal applicability. The representative of Cyprus stated in the plenary meeting of the General Assembly that:

Although the African-Asian draft resolution is mainly concerned with the granting of independence to colonial countries and peoples, yet it is in no way restricted. Its scope, in terms of freedom and self-determination, is all-embracing. It includes all peoples, in whatever land and in whatever circumstances they are dominated and by whatever means they are deprived of their inalienable right to self-determination and freedom. ${ }^{40}$

Similar views were expressed by other member states. For example, the representative of Ecuador said that:

${ }^{47}$ This resolution was based upon a text proposed by forty-three Afro-Asian member states of the United Nations. About seventy-two delegations participated in a general debate on the resolution which lasted from November 28, 1960, to December 14, 1960. For the debates, see U.N. GEN. Ass. OfF. REc. 15th Sess., Plenary 981 (A/PV.925) (1960). A summary of the debates and the text of the resolution is also published in U.N. REV., Jan. 1961, pp. 6-9, 37-41. This resolution was adopted by the General Assembly without dissent. Australia, Belgium, Dominican Republic, Portugal, the Union of South Africa, the United Kingdom and the United States, however, abstained from voting.

${ }^{8} \mathrm{Mr}$. Tsiang of China was of the opinion that the clause applied to all types of colonialism. He stated that: "A colony is a colony, whether it is the product of overseas expansion or the product of overland expansion." U.N. GEN. Ass. OFF. REc. 15th Sess., Plenary 1145 (A/PV.935) (1960).

${ }^{\circ}$ U.N. Gen. Ass. Off. Rec. 15th Sess., Plenary 1256 (A/PV.945) (1960). 
This principle [of self-determination] must, however, be exercised broadly without discrimination and without admitting exclusivist subtleties or fallacious exceptions, whether from the side of classic colonialism or of neocolonialism, and whether from the left or the right. ${ }^{50}$

The resolution also bears upon the question of the exercise of sovereignty in a colonial territory. It declares that "all peoples have an inalienable right to complete freedom, the exercise of their sovereignty and the integrity of their national territory." What does this signify? What freedoms are referred 'to? What is meant by "integrity of their national territory"? These are all difficult questions to answer, but one can perceive the general direction in which the winds of change are blowing. The following statement of the Iranian representative, in the plenary meeting of the Assembly, probably serves to enlighten the meaning of this passage:

The colonial Powers must recognize that one of the first and most important attributes of a people's independence is the exercise of sovereignty, which is the sole prerogative of those living within the national territory. Sovereignty appertains to them both defacto and dejure and no one may exercise it on their behalf without their freely-given consent. ${ }^{51}$

From this it would appear that sovereignty in a colonial territory belongs to the people, and that the exercise of it slould be in accordance with the wishes of the colonial peoples.

The most important aspect of the resolution, however, consists in its providing substance to an otherwise abstract concept of selfdetermination. The resolution not only declares that all peoples have a right of self-determination, but proclaims that "by virtue of that right they freely determine their political status and freely pursue their economic, social and cultural development." In other words, the concept of self-determination has more than political content; indeed, it appears as a comprehensive doctrine encompassing economic, social and cultural factors. According to the Venezuelan representative, the principle of self-determination includes

the right of every people to choose its own form of government, to enjoy its spiritual and material patrimony without restriction, to live freely in accordance with its most cherished traditions, and

${ }^{50}$ U.N. Gen. Ass. OFf. Rec. 15th Sess., Plenary 1101 (A/PV.933) (1960).

${ }^{51}$ U.N. Gen. Ass. Off. Rec. 15th Sess., Plenary 994 (A/PV.926) (1960). 
to be exempt from any form of subjection to any other more powerful nation or people. ${ }^{52}$

It purports to condemn all forms of domination. It seeks to remove the evils of colonialism involving "political captivity, economic domination, social enslavement and cultural subjugation . . .."53

Debate in the General Assembly was also concerned with the question of the compatibility of the resolution with the Charter. The case of the sponsoring members was put forward by Ceylon as follows:

After all, it does not require great intelligence or great wisdom to see that Article 73, 76 and, what is more, Article 1, paragraph 2, of the Charter, or Article 55, are very simple matters, propositions which are accepted by the world community, and yet, in the implementation of these Articles we find that these authorities have not conformed to the obligations, and that is, as I say, the justification for our draft resolution. ${ }^{54}$

Similar views were expressed by other member states. ${ }^{55}$ In the interpretation of the sponsoring members, this declaration says nothing more than what is already contained in the United Nations Charter. It only clarifies the principle of self-determination contained in the Charter. ${ }^{56}$

That self-determination is not an empty phrase, but a principle of law which can be applied to contemporary world politics, may be demonstrated by reference to such concrete cases as Angola and Malaysia.

\section{The Case of Angola}

At one time Portugal argued that there was no need to apply the principle of self-determination to Angola. ${ }^{57}$ This argument did

\footnotetext{
B2 U.N. Gen. Ass. OFF. Rec. 15th Sess., Plenary 1200 (A/PV.939) (1960).

va U.N. Gen. Ass. OfF. Rec. 15th Sess., Plenary 1012 (A/PV.927) (1960).

s. U.N. Gen. Ass. OFf. Rec. 15th Sess., Plenary 1002 (A/PV.926) (1960).

${ }^{\triangle B}$ See the statement of the Philippines representative. U.N. GEN. Ass. OFF. REC. 15th Sess., Plenary 1103 (A/PV.933) (1960).

${ }^{\circ}$ The interpretation of the United States, however, was that some of the terms of the resolution go beyond the language of the Charter. U.N. GEN. Ass. OFF. REc. 15th Sess., Plenary 1283 (A/PV.947) (1960).

${ }^{67}$ In its comments on the report of the Subcommittee on the Situation in Angola, the Portuguese delegation emphasized that "there have never been demonstrations with this purpose [viz., self-determination] in view which have had to be repressed by the authorities." Report of the Special Committee on Territories under Portuguese Administration, U.N. GEN. Ass. OFF. REc. 17th Sess., Annexes, Agenda Item No. 54, at 32 (A/5160) (1962). In June 1961, Premier Salazar is reported to have announced that there was no need for the expression of self-determination by the people of the
} 
not find favor with the United Nations, however, which declared more than once that the principle of self-determination should apply. ${ }^{58}$ In the latest resolution on the subject, the Security Council called upon all states to comply with a former resolution calling upon Portugal to implement the immediate recognition of the right of peoples of the territories under its administration to self-determination and independence. The Angolans themselves agitated for independence. ${ }^{59}$ The United Nations Special Committee on Territories under Portuguese Administration reported that representatives of various political organizations which it had examined told the committee that their organizations were dedicated to the attainment of independence. ${ }^{60}$ The National Front for the Liberation of Angola (FNLA) announced in 1962 that it had set up a provisional Angolan government-in-exile in the Congo. ${ }^{61}$

There is perhaps little justification today for the argument that the principle of self-determination does not apply to Angola. It is of some interest to mark the recent changes in the Portuguese position in regard to Angola. No longer does Portugal argue that self-determination does not apply; it only maintains that the meaning attributed to self-determination in the United Nations' resolutions is incorrect. In this connection the precise argument of the Portuguese foreign minister, who participated in the joint talks between Portugal and the African states, was to the effect that:

Frankly, Portugal was opposed to a certain concept of self-determination which is predetermined in its results and which ignores all acts unless they are done in accordance with certain resolutions or criteria. Portugal did not believe that self-determination could be predetermined. Portugal believed that there was more than one modality of self-determination just as there was more than one modality with regard to the form of administration of a State. Self-determination to Portugal meant the agreement and consent

overseas territories for "this was done long ago and is expressed and confirmed in the Constitution." Ibid.

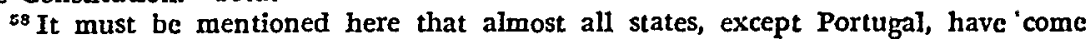
to regard the principle of self-determination as applicable to Angola. For cxample, Mr. Adlai Stevenson, U.S. Ambassador to the United Nations, stated that "in the view of the United States delegation, three great principles are involved. First is the principle of self-determination ...." 46 DEP'T STATE BuLL. 385 (1962).

${ }^{60}$ For an account of the objectives of the political parties of the Angolans in and outside Angola, See U.N. GEN. Ass. OFF. Rec. 16th Sess., Supp. No. 16, at 42 (A/4978) (1962); U.N. GeN. Ass. OFf. Rec. 17th Sess., Annexes, Agenda Item No. 54, at 28-35 (A/5160) (1962)

${ }^{\circ}$ Id. at 81 .

${ }^{01}$ N.Y. Times, April 6, 1962, p. 1, col. 1. 
of the population to a certain political structure, type of State and administrative organization. ...

To Portugal, self-determination meant the consent of the people to a certain structure and political organization. It came about by participation in administration and by participation in political life. ${ }^{62}$

This interpretation of self-determination, however, was opposed by the spokesmen for the African States of Liberia, Madagascar, Sierra Leone and Tunisia, who asserted that "it was essential that the people of the Portuguese Territories should be able to make the important decisions as to what their present and future political relationship with Portugal should be."63 Thus we see differences of opinion between Portugal and the African states with regard to the scope of self-determination. However, the fact that Portugal even agreed to discuss the Angolan problem with the African states at a conference table and recognized the relevance of self-determination to the Angolan problem is highly significant. It probably serves to show the impact of the United Nations, on the one hand, and the reality of the concept of self-determination on the other. As to the relative merits of the arguments advanced by the interested states on the scope of self-determination, we have already stated that self-determination derives its content from the decisions of the organs of the United Nations. Accordingly, Angolans have the right to determine freely their political status and pursue their economic, social and cultural development. This means that the Angolans can have complete independence or any other status which the Angolans themselves freely determine. The United Nations is there to insure that the decisions Angolans arrive at have been arrived at voluntarily. Portugal surely cannot legally dictate the political future of Angola.

\section{The Case of Malaysia}

The case of Malaysia serves as another illustration of the application of the principle of self-determination. Not infrequently, it is supposed that self-determination is a force for promoting secessionary tendencies among national groups within states. But from the Malaysian situation we learn that self-determination has other

\footnotetext{
${ }^{62}$ Report by the Secretary-General in Pursuance of the Resolution Adopted by the Security Council at its 1049th Meeting on 31 July 1963 (S/5380), U.N. Doc. No. S/5448, at 4 (1963).

08 Id. at 5 .
} 
dimensions also. In the case of Malaysia, the Secretary-General of the United Nations was entrusted with the task of ascertaining, prior to the establishment of the Federation of Malaysia, the wishes of the people of Sabah (North Borneo) and Sarawak on the question of the proposed federation. The Secretary-General was specifically required to insure that principle IX of resolution 154I (XV) ${ }^{64}$ was complied with by the parties. Indonesia and the Philippines, two of the States which opposed the formation of the federation, stated that they would welcome Malaysia if the Secretary-General were satisfied that there had been compliance with the resolution. The Secretary-General accepted the task and appointed a United Nations mission to go to the scene and ascertain the facts relating to the consent of the people living in Sabah and Sarawak on the issue of the federation. "The United Nations Malaysia Mission reported [in 1963] . . . that a great majority of the people of Sarawak and Sabah (North Borneo) favored participation of the two territories in the proposed Federation of Malaysia." adopted three different modalities for ascertaining the wishes of the people. First, there was consultation with the legislative institutions in the two territories. In Sarawak, the territory's highest legislative body authorized the governor to initial the draft agreement for the federation on behalf of Sarawak. There was similar action by the highest legislative organ of Sabah. The second modality adopted by the United Nations mission was that of consultation with representatives of the people in the above territories. This consultation disclosed, according to the mission report, that the representatives expressed themselves in favor of the proposed Federation of Malaysia by a margin of better than two to one. The third device employed by the mission was to collect the opinion of the electorate in Sarawak and Sabah on the Malaysia issue. About 61 per cent of the people of Sarawak were found to favor Malaysia, 22.2 per cent opposed the fed-

\footnotetext{
at Principle IX provides as follows: "Integration should have come about in the following circumstances: (a) the integrating territory should have attained an advanced stage of self-government with free political institutions, so that its peoples would have the capacity to make a responsible choice through informed and democratic processes; (b) The integration should be the result of the freely expressed wishes of the territory's peoples acting with full knowledge of the change in their status, their wishes having been expressed through informed and democratic processes, impartially conducted and based on universal adult suffrage. The United Nations could, when it deems it necessary, supervise these processes." U.N. REv., Aug.-Sept. 1968, p. 12.

es U.N. Rev., Oct. 1963, p. 11.
} 
eration, and 16.8 per cent remained neutral. The mission similarly found that a great majority of the people of Sabah supported the proposed Federation of Malaysia. The mission also consulted with nonpolitical groups and organizations, the results of which indicated that the issue of Malaysia was widely discussed among the people at the time of the elections, and that a majority favored the proposed federation. The mission found several motives, such as security and economic considerations, for supporting the proposed federation. There was also an expectation that the proposed federation would lead to harmony among the several ethnic groups living in the territories.

The Malaysia mission also considered the effect of political detention of persons eligible to vote on the issue of federation and concluded, in the words of the Secretary-General, that "the actual votes of this group would not have been sufficient to have had a material effect on the result."66 The Secretary-General accepted the findings of the mission and reported to the parties to the Manila Agreement that there was complete compliance with the principle of self-determination within the requirements of principle IX of resolution 1541 (XV) of the General Assembly. It is of some interest to note that although principle IX is contained in a General Assembly resolution which lists "principles which should guide Members in determining whether or not an obligation exists to transmit information called for under Article 73 (e) of the Charter," it was applied here in a case involving the issue of self-determination of peoples. This tends to indicate the interrelationship between decolonization and self-determination and the usefulness of the principles developed in the context of decolonization to the issue of self-determination in general.

\section{A Retrospect}

One of the main points that emerges from the present study is that self-determination constitutes one of the modern principles of international law. It derives its validity principally from the Charter of the United Nations. The Charter does not, however, define the concept any more than it does aggression or domestic jurisdiction. One has to look to the various resolutions of the organs of the United Nations to ascertain its meaning and content. It is, indeed,

\footnotetext{
"Id. at 15. For the Secretary-General's conclusions on the Malaysia mission, see id. at $14-15$.
} 
the body of precedents in the United Nations that enriches the principle of self-determination.

One of the questions that has been raised in connection with the principle of self-determination concerns the circumstances or cases in which it can be applied. It is extremely difficult, if not impossible, to visualize the different kinds of cases in which the principle of self-determination can be employed. This is no less true, however, with regard to other concepts referred to in the United Nations Charter. What can be done is to utilize the body of precedents developed in the United Nations in similar circumstances.

The principle of self-determination has so far been invoked only in the context of decolonization. More specifically, it was invoked by peoples living in colonial territories seeking self-government or independence. Cases in point are Indonesia, Algeria, and Cyprus. In these cases the principle operated as a force for the separation of territory from a state. But self-determination has other dimensions also. In the case of Malaysia it was demonstrated that self-determination can be an instrument for integration and unification, which, of course, must be based upon the freely expressed wishes and desires of the people claiming the interest or right in question. The resolutions of the organs of the United Nations serve generally as guidelines in determining the nature of the wishes of a people. In ascertaining the wishes of a people, one can employ any modality that is best under the circumstances. The United Nations can and should operate as the legal instrumentality for upholding or negating the claims of self-determination of a group of people in a particular case.

The right of self-determination extends to economic, social and cultural matters. The fact that it has so far not been employed for this purpose, or employed to the same degree as in the case of political matters, does not in any way preclude its being invoked on future occasions.

The question has also been raised as to whether the right of self-determination belongs to an individual or to a group of people. The cases that have come up for discussion and decision in the United Nations would seem to suggest that the right of self-determination belongs to a collectivity rather than to an individual. Cases in point are those involving the Aaland Islands and Malaysia. This is not to say that self-determination cannot become an individual 
right; but so far no efforts have been made to vest in the individual the right of self-determination. ${ }^{67}$

The principle "of self-determination represents an important movement away from the old legal view under which international law rights pertain only to states and governments, and not to groups or individuals." 68 A logical corollary of this development is that matters covered by self-determination are automatically lifted from domaine reservé and are regulated by international law and the United Nations. ${ }^{09}$

or Even the so-called Draft Covenants on Human Rights do not confer the right of self-determination on an individual. See SoHN, Basic Documents of THE UNITEd Nations 136 (1956).

os Higgins, The Development of International Law Through the Political Organs of the United Nations 106 (1963).

${ }^{\circ}$ Id. at 103. 